\title{
Observations of Near-Surface Mixing Behind a Headland
}

\author{
Preston Spicer *(D) and Kimberly Huguenard (D) \\ Department of Civil and Environmental Engineering, University of Maine, Orono, ME 04469, USA; \\ kimberly.huguenard@maine.edu \\ * Correspondence: preston.spicer@maine.edu
}

Received: 20 December 2019; Accepted: 20 January 2020; Published: 22 January 2020

\begin{abstract}
Field observations were collected near the mouth of the Bagaduce River, Maine, in order to understand how complex features affect the intratidal and lateral variability of turbulence and vertical mixing. The Bagaduce River is a low-inflow, macrotidal estuary that features tidal islands, tidal flats and sharp channel bends. Profiles of salinity, temperature, and turbulent kinetic energy dissipation $(\varepsilon)$ were collected for a tidal cycle across the estuary with a microstructure profiler. Lateral distributions of current velocities were obtained with an acoustic doppler current profiler. Results showed intratidal asymmetries in bottom-generated vertical eddy diffusivity and viscosity, with larger values occurring on ebb $\left(K_{z}: 10^{-2} \mathrm{~m}^{2} ; A_{z}: 10^{-2} \mathrm{~m}^{2} / \mathrm{s}\right)$ compared to flood $\left(K_{z}: 10^{-5} \mathrm{~m}^{2} / \mathrm{s} ; A_{z}\right.$ : $10^{-4} \mathrm{~m}^{2} / \mathrm{s}$ ). Bottom-generated mixing was moderated by the intrusion of stratified water on flood, which suppressed mixing. Elevated mixing $\left(K_{z}: 10^{-3} \mathrm{~m}^{2} ; A_{z}: 10^{-2.5} \mathrm{~m}^{2} / \mathrm{s}\right)$ occurred in the upper water column in the lee of a small island and was decoupled from the bottom layer. The near-surface mixing was a product of an eddy formed downstream of a headland, which tended to reinforce vertical shear by laterally straining streamwise velocities. These results are the first to show near-surface mixing caused by vertical vorticity induced by an eddy, rather than previously reported streamwise vorticity associated with lateral circulation.
\end{abstract}

Keywords: estuary circulation; vertical mixing; turbulence; eddies

\section{Introduction}

Estuarine circulation is responsible for the transport and fate of sediments, pollutants, and organisms between marine and freshwater environments. The strength of the circulation ultimately dictates the productivity and overall health of an estuary [1], which are particularly important variables in estuaries containing aquaculture operations, such as the study site in the present paper. This subtidal flow was traditionally thought to be a balance between the barotropic and baroclinic pressure gradients and friction [2,3]. In that classic balance, friction is linearized using a constant eddy viscosity acting on the mean vertical gradients of velocity. More recent work identified that nonlinear advection and tidal asymmetries in vertical mixing (stress divergence) had the potential to modify tidally averaged flows [4-6]. Advection and mixing are both locally modified in estuaries, making asymmetries in each very site dependent and variable in their importance on net flows. The new significance of the stress divergence term in subtidal currents showed that circulation was not always dominated by the baroclinic and barotropic pressure gradients [7-9]. Multiple other mechanisms could create asymmetries in stress divergence and therefore influence subtidal currents.

The theory behind mechanisms responsible for tidal variations in stress divergence has evolved through time, with recent research coining it as the eddy viscosity-shear covariance (ESCO) [10]. ESCO circulation is represented by the vertical turbulent momentum flux [11]: $A_{z} \frac{\partial u}{\partial z}$, where $A_{z}$ is the eddy viscosity and $\frac{\partial u}{\partial z}$ is the vertical gradient in along-channel velocity. In terms of traditional tidal straining, 
ESCO occurs when increased stratification reduces $A_{z}$ on ebb tide and subsequently enhances $\frac{\partial u}{\partial z}$, with the opposite occurring on flood (e.g., $[8,12,13])$. In that scenario, enhanced mixing on flood tides relative to ebb enhances the classical estuarine circulation of seaward flow near surface countered by landward flow at depth through ESCO. It has also been shown that the opposite case (stronger mixing on ebb than flood) creates an ESCO flow countering classic circulation (e.g., [10,14]). Collectively, circulation driven by mixing asymmetries from ESCO can be equally or even more important than traditional buoyancy driven flow (e.g., [15]). The former work on ESCO circulation focuses on generally parabolic or linear profiles of $A_{z}$ created from bottom-generated turbulence. Although the effects of varying temporal patterns of $A_{z}$ from bottom stress on ESCO have been elucidated, the effect of non-classical spatial patterns in $A_{z}$, like enhanced near-surface mixing, are less obvious.

Near-surface mixing on the continental shelf has been observed and attributed to surface tides interacting with steepening bottom bathymetry [16]. In estuaries, near-surface mixing can arise from lateral processes that is decoupled from bottom stress. The lateral straining of velocity shears, lateral density gradients and Coriolis acceleration have all promoted vertical mixing to form near the surface or subsurface during mid to late ebb [17-19]. These previous studies have highlighted the importance of channel-shoal morphology in the development of mixing driven by lateral processes. What has not been previously reported is if lateral processes generated by along-channel variations in bathymetry can cause near-surface mixing. Near-surface mixing is clearly important for the vertical exchange of momentum and is increasingly being reported in various systems (e.g., [20-22]).

The goal of this work, therefore, is to use field observations to determine whether along-channel variations in bathymetry, and specifically headlands, can influence mixing decoupled from the bottom. The research objectives are to (1) identify near-surface turbulence and mixing in a headland-induced eddy and (2) diagnose the forcing mechanisms responsible for vertical mixing. The remaining sections of this paper begin with a background on the study area and data collection/analysis (Section 2). A detailed account of observations is presented in the Results (Section 3), outlining a more mixed water column on ebb tide with enhanced bottom-generated and near-surface mixing relative to flood. In Section 4, an analysis of flow structure and mixing shows the importance of shear straining, induced by an eddy formed by a headland, in destabilizing the near-surface water column. The conclusions are presented last in Section 5.

\section{Materials and Methods}

\subsection{Study Area}

Data for this experiment were collected in the Bagaduce River, which is a tributary to Penobscot Bay on the central coast of Maine in the New England region of the United States (Figure 1). The Bagaduce River is a short and shallow estuary, extending approximately $20 \mathrm{~km}$ from the mouth inland to a small dam at Walker Pond, the primary source of freshwater. Aquaculture in the form of oyster farming has increased in the estuary over the past decade, renewing interest in understanding the hydrodynamic processes and water quality of the system [23]. This work was conducted to better elucidate these processes in the estuary and is the first hydrodynamic study of the Bagaduce River. The estuary has variable morphology, including extensive tidal flats, islands, and constrictions. At the mouth, the estuary is approximately $550 \mathrm{~m}$ wide, while the smallest constriction is located at a bridge near the head and is approximately $15 \mathrm{~m}$ wide. That location is known as the "reversing falls", as a hydraulic jump occurs on either side of the constriction depending on the phase of tide. The widest cross sections with tidal flats exceed $2 \mathrm{~km}$ in the middle reaches of the estuary. Channel depths range from approximately $30 \mathrm{~m}$ at the mouth to $3 \mathrm{~m}$ near the head. A watershed approximately $195 \mathrm{~km}^{2}$ in area drains into the estuary. The Bagaduce River is a low-inflow system and has a mean annual freshwater discharge of $4.4 \mathrm{~m}^{3} / \mathrm{s}$. High runoff periods generally occur during the spring freshet in May while the lowest runoff period is typically September, with mean monthly discharges of $14 \mathrm{~m}^{3} / \mathrm{s}$ and 
$0.85 \mathrm{~m}^{3} / \mathrm{s}$, respectively [24]. Nonlinear tide-surge interaction has been observed at the mouth of the Bagaduce River from overtide enhancement during storm events [25].

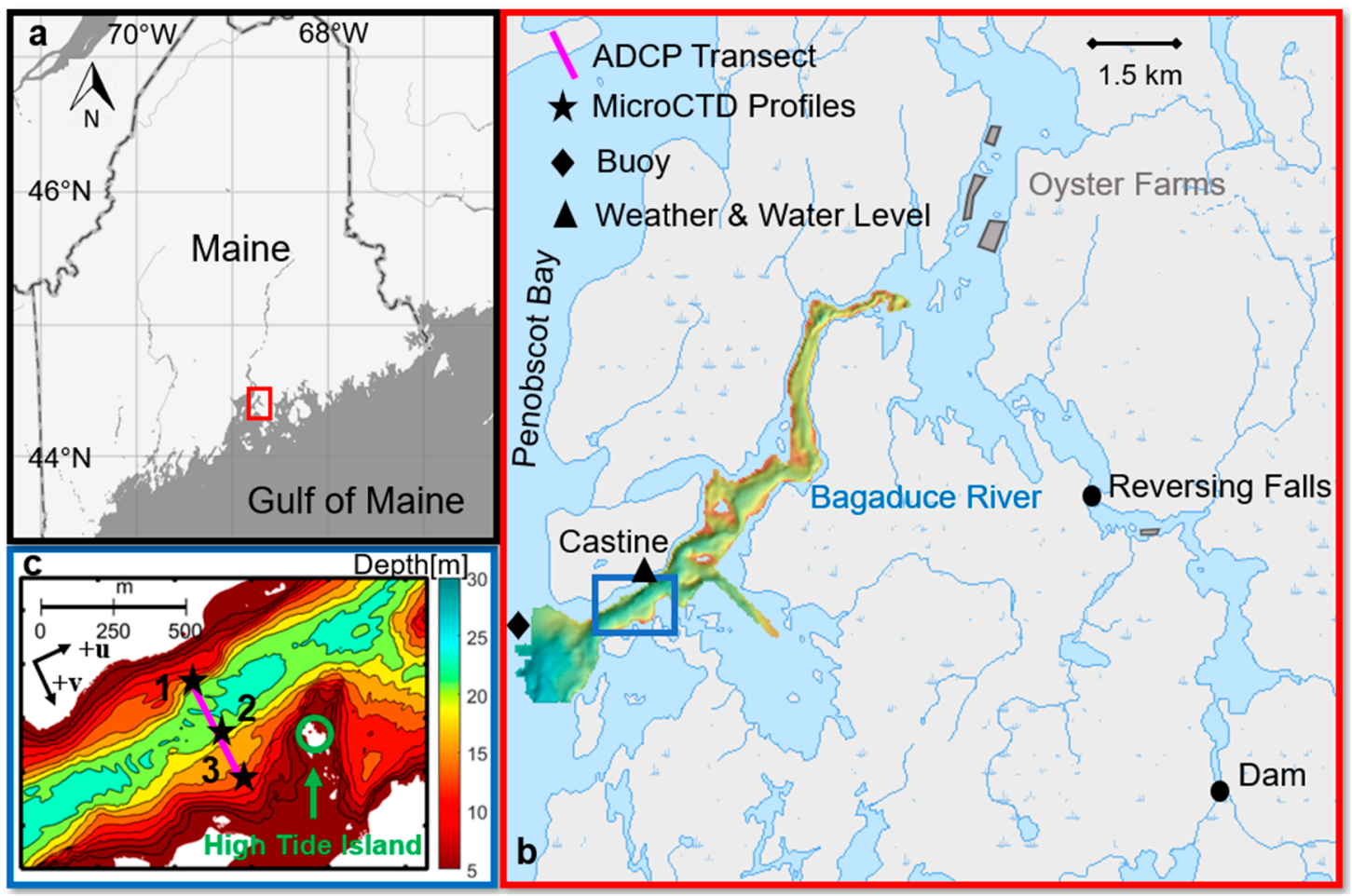

Figure 1. (a) The study area in relation to Maine, with the Bagaduce River located in the red box. (b) A zoom in on the Bagaduce River with depth indicated by contours. Weather station/water level (triangle) and buoy (diamond) locations are marked. Approximate locations of oyster farms are indicated by gray boxes. (c) A zoom in on the data collection transect location at the mouth of the estuary. An acoustic doppler current profiler (ADCP) sampled along the magenta line and MicroCTD profiles were taken at each station (stars).

The Bagaduce River is connected to the hydrodynamic processes of Penobscot Bay given its proximity. In the Penobscot River, the tide is primarily semidiurnal with a neap/spring range of approximately 3 to $5 \mathrm{~m}$, making the estuary macrotidal [26]. Tidal ranges are similar in the Bagaduce River at the mouth, then damp to 0.3 to $0.38 \mathrm{~m}$ at the head (for neap and spring, respectively), upstream of the reversing falls [27]. Tidal velocity amplitudes average near $1 \mathrm{~m} / \mathrm{s}$, with neap to spring ranges of $0.7 \mathrm{~m} / \mathrm{s}$ to $1.3 \mathrm{~m} / \mathrm{s}$. The Penobscot River is relatively well-mixed at the confluence with the Bagaduce River, existing approximately $10 \mathrm{~km}$ seaward of a salt-wedge/partially stratified region (depending on river discharge) [26]. River discharge in the region is from the combined Penobscot River and Kenduskeag Stream (flows into the Penobscot at Bangor), with a mean annual discharge at the confluence of $369 \mathrm{~m}^{3} / \mathrm{s}$ [28]. High run-off periods generally occur during the spring freshet (April to May), with a mean monthly discharge of $1105 \mathrm{~m}^{3} / \mathrm{s}$, while the lowest runoff period is usually September, with a mean monthly discharge of $140 \mathrm{~m}^{3} / \mathrm{s}$ [29].

The study location was located near the mouth of the Bagaduce River, seaward of a small island known as High Tide Island (Figure 1c). At low tides, depths of less than $1 \mathrm{~m}$ often separate High Tide Island from the mainland, making the island behave more as a headland. A point of similar shallow water depths also extends from the island towards the channel, before sharply increasing. For the sake of this paper, the island and shallow water that surround it will be referred to as a headland. Many such islands and headland features exist in Maine estuaries, which are often morphologically complicated, i.e., many constrictions, islands, headlands, sharp bends, tidal flats, etc. Bottom sediments near the sampling location are unknown. 


\subsection{Data Collection}

A tidal cycle survey was performed near the mouth of the Bagaduce River on 16 October 2017. The ship towed a $1200 \mathrm{kHz}$ RDI Workhorse Sentinel acoustic doppler current profiler (ADCP) downward facing on a trimaran across the estuary every $30 \mathrm{~min}$, which measured lateral distributions of east-west and north-south velocities at $1 \mathrm{~Hz}$. Measurements were taken in $0.5 \mathrm{~m}$ bins for one semi-diurnal tidal cycle (12.42 h), resulting in 25 transects from station 1 to 3 (Figure 1c). Station 1 was located on a sharp channel-shoal interface near the north-west shoal, station 2 was in the channel, seaward of the High Tide Island headland, and station 3 was located on the south-east shoal, directly seaward of High Tide Island. During ADCP transects, the boat speed was maintained around $1.3 \mathrm{~m} / \mathrm{s}$.

A Rockland Scientific MicroCTD collected microstructure profiles at each station along transect repetitions (Figure 1c). The $25 \mathrm{ADCP}$-only transects began at station 1 and ended at station 3, while the transect repetitions that included MicroCTD profiles began at station 3 and ended at 1 each time, totaling 23 transects over nearly one semidiurnal tidal cycle. The MicroCTD provides direct estimates of turbulent kinetic energy (TKE) dissipation rates, $\varepsilon$, which were used to calculate the vertical eddy viscosity, $A_{z}$, and vertical eddy diffusivity, $K_{z}$, both of which are used as proxies for vertical mixing of momentum and buoyancy, respectively [11]. The direct estimates from the MicroCTD allow for more accurate calculations of $\varepsilon$, which has been difficult to parameterize in the past [11].

Two shear probes on the nose of the instrument measure the vertical shear in horizontal flow velocity $\left(\frac{\partial u}{\partial z}\right.$ and $\left.\frac{\partial v}{\partial z}\right)$ at $512 \mathrm{~Hz}$ in two orthogonal components. The vertical shear was then used to estimate $\varepsilon$ at each probe. Electrical conductivity and temperature were also measured at the same frequency with a conductivity probe and thermistor. The profiler was deployed downward and achieved a terminal velocity of $0.85 \mathrm{~m} / \mathrm{s}$ after $1.5 \mathrm{~m}$. The instrument was deployed in bursts of 4 casts at each station and averaged in order to limit bias from small scale intermittency. Averaging together four casts has been shown to be sufficient in similar regions with complex morphology [30]. Vertical casts did not reach the bottom, to avoid collision with the sea-bed and damage to the probes.

Water levels and wind data were collected at Castine, located $0.5 \mathrm{~km}$ from the transect location $\left(44.38694{ }^{\circ} \mathrm{N},-68.79676^{\circ} \mathrm{W}\right)$. Water levels were calculated using absolute pressure from a HOBO water level logger sampling in 2 min intervals and barometric pressure from the Maine Maritime Academy weather station. Wind speed and direction were also sampled at the weather station in 1 min intervals and low-pass filtered over $2 \mathrm{hr}$. to smooth the data. A buoy in eastern Penobscot Bay near the mouth of the Bagaduce River (called Dice Head $\left[44.37619^{\circ} \mathrm{N},-68.83023^{\circ} \mathrm{W}\right]$ ) calculated density anomaly $\left(\sigma_{\mathrm{a}}\right)$ at the surface $(2 \mathrm{~m})$ and bottom $(25 \mathrm{~m})$ in 20 min intervals. Penobscot River discharge was measured in $15 \mathrm{~min}$ intervals at a USGS gage (\#01034500 at $45.23714^{\circ} \mathrm{N},-68.65085^{\circ} \mathrm{W}$ ) in West Enfield, $100 \mathrm{~km}$ north of the transect location.

\subsection{Data Processing and Analysis}

\subsubsection{Hydrographic Data}

The velocity data collected with the ADCP were ensemble averaged (10 ensembles per average, equaling $10 \mathrm{~s}$ each) and interpolated onto uniform grids with $2 \mathrm{~m}$ resolution across estuary and $0.5 \mathrm{~m}$ in depth. Velocity measurements in the bottom $10 \%$ of the water column were excluded due to side-lobe interference with the bottom. Any data ensemble with a signal return of less than $85 \%$ good data and error velocities greater than $10 \%$ of maximum flow were excluded. Remaining data were corrected through a comparison of bottom track velocities to GPS-determined velocities [31]. Vertical and lateral gradients (shears) in velocities were bin averaged to show the statistical relationship between the two variables.

On the microstructure transects, velocity profiles were extracted from the ADCP according to MicroCTD cast times, thus resulting in velocity time series for each station. This allowed for accurate measurement of currents at the exact times and locations the turbulence profiler was deployed. The $\mathrm{ADCP}$-only transects complemented these data by allowing cross sections of velocities through time. All 
currents were rotated from the corrected east-west $(u)$ and north-south $(v)$ components to streamwise $(u)$ and stream-normal $(v)$ velocities according to Rhoads and Kenworthy (1998) [32]. Positive $u$ is current directed landward, while positive $v$ is directed toward the southeast shoal. To organize and compare the shear data in a statistically significant manner, a bin averaging technique was used which averages shear values within particular ranges (bins) to one value per bin. This technique reduces minor observation errors. Bins of $\frac{\partial u}{\partial y}$ were formed every $0.018 \mathrm{~s}^{-1}$ from a minimum of 0 to a maximum of $1.5 \mathrm{~s}^{-1}$. Corresponding values of vertical shears (in both $u$ and $v$ ) were then averaged to form one point per bin. Only bins with a number of sample points, $n$, greater than 30 were used to reduce error in averaging. Maximum $n$ values were near 21,000.

\subsubsection{TKE Dissipation Rate, $\epsilon$}

Values for $\epsilon$ were determined by integrating the velocity shear spectrum, $\psi$, in wavenumber space [33] with the assumption that turbulence is homogeneous and isotropic:

$$
\epsilon=\frac{15}{2} \frac{\mu}{\rho} \overline{\left(\frac{\partial u}{\partial z}\right)^{2}}=\frac{15}{2} \frac{\mu}{\rho} \int \psi(k) d k,
$$

where $\mu$ is the dynamic viscosity and $k$ is the wavenumber. Spectra were integrated using the RSI vertical profiler processing software, ODAS, which uses the Nasmyth spectrum to integrate beyond the unresolved part of the spectral variance. A fast Fourier transform (FFT) length of $0.5 \mathrm{~s}$ was chosen to resolve the wavenumbers of interest. Each profile was then individually checked for several quality controls. The Goodman noise removal algorithm was used to correct for profiler vibrations [34]. Profiles where the instrument inclination exceeded $5^{\circ}$ on descent were excluded. At each depth for each cast, estimates of $\varepsilon$ for each probe were compared and averaged. If the estimates between probes varied by more than a factor of 2 , the larger value was not used in the averaging as they likely represented particulates hitting the shear probe [35]. Finally, burst averaged profiles of $\varepsilon$ were then interpolated onto a uniform depth grid with $0.5 \mathrm{~m}$ intervals (the same as the ADCP grid).

\subsubsection{Turbulent Mixing}

Using TKE dissipation estimates, $A_{z}$ and $K_{z}$ were calculated at each station over the tidal cycle to quantify intratidal variation in vertical mixing throughout the water column. The process followed that of Kay and Jay (2003) [36]:

$$
\begin{aligned}
A_{z} & =\Gamma_{m} \frac{\epsilon}{S^{2}}, \\
K_{z} & =\Gamma_{m} \frac{\epsilon}{N^{2}},
\end{aligned}
$$

where $\Gamma_{m}$ is the mixing efficiency factor (Equations (5) and (6) below) and $S^{2}$ is the squared vertical shear in velocity, calculated as:

$$
S^{2}=\left(\frac{\partial u}{\partial z}\right)^{2}+\left(\frac{\partial v}{\partial z}\right)^{2}
$$

where $z$ is the vertical coordinate with positive being upward. Vertical shear estimates that were smaller than the velocity resolution of the ADCP $\left(\frac{\partial u}{\partial z}, \frac{\partial v}{\partial z}<0.1 \mathrm{~cm} / \mathrm{s} / 50 \mathrm{~cm} / \mathrm{s}<2 \times 10^{-5} \mathrm{~m} / \mathrm{s}\right)$ were removed and interpolated.

The mixing efficiency factor used in $A_{z}$ was calculated as:

$$
\Gamma_{m}=\frac{1}{1-R_{f}}
$$


whereas, for $K_{z}$ :

$$
\Gamma_{m k}=\frac{R_{f}}{1-R_{f}},
$$

where $R_{f}$ is the flux Richardson number. $R_{f}$ is estimated using the turbulent Prandtl number, $P r_{t}$, and the gradient Richardson number, $R i$, as:

$$
R_{f}=R i P r_{t},
$$

The upper limit of $R_{f}$ was set to 0.18 , as values above that do not allow turbulence to be maintained at a steady state [37]. The Richardson number used in Equation (7) is a ratio of the buoyancy frequency, $N^{2}=\frac{-g}{\rho_{0}} \frac{\partial \rho}{\partial z}$, where $\rho$ is density, to squared vertical shear (Equation (4)):

$$
R i=\frac{N^{2}}{S^{2}}
$$

with $R i=0.25$ taken as the critical threshold $(R i>0.25)$ where stratification can suppress shear-driven mixing [38,39]. $P r_{t}$ is then a function of $R i$ according to Tjernstrom's parameterization [40]:

$$
P r_{t}=(1+4.47 R i)^{0.5}
$$

\section{Results}

The intratidal and spatial variability in currents, stratification, and vertical mixing were explored from the 16 October 2017 tidal cycle survey. Cross sections of currents are presented for two transects taken during maximum flood and ebb tidal phases; and time series of currents, buoyancy frequency, Richardson number, TKE dissipation rates, and vertical mixing were presented at stations 1 and 2, as those locations exhibited the most notable mixing patterns.

\subsection{Environmental Conditions and Penobscot River Forcing}

The tidal range in the Bagaduce River at the time of the survey was typical of an average tide $(3.75 \mathrm{~m})$, part way between a neap and spring tide (Figure 2a). The top-to-bottom density differences near the mouth of the Bagaduce River were generally smallest at the end of ebb tides $\left(<2 \mathrm{~kg} / \mathrm{m}^{3}\right)$ and largest at the end of floods $\left(>2 \mathrm{~kg} / \mathrm{m}^{3}\right)$, although there was not always a noticeable intratidal variation (day 15 in Figure 2b). This indicated a more stratified water column on flood relative to ebb. Winds blew approximately south and east during the survey, and wind speeds were relatively weak $(<3 \mathrm{~m} / \mathrm{s})$ throughout sampling (Figure 2c). Discharge in the Penobscot was typical of the dry season $\left(140 \mathrm{~m}^{3} / \mathrm{s}\right.$ ) during sampling (Figure 2d). 
(a) Water Level

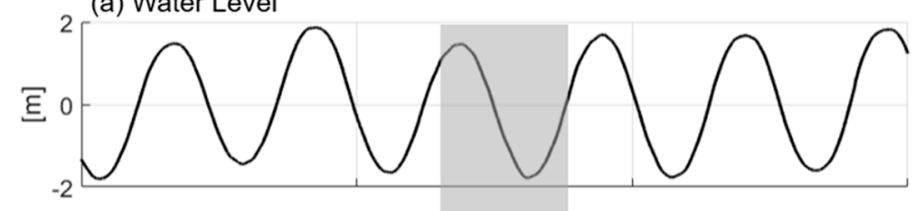

(b) Surface to Bottom Difference in Density, Penobscot

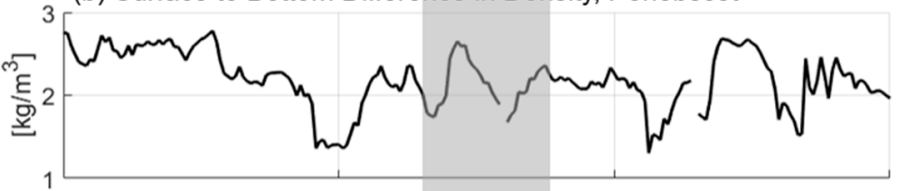

(c) Wind Speed and Direction

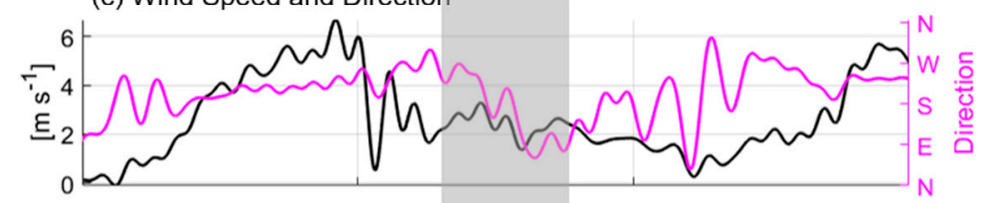

(d) Penobscot River Discharge

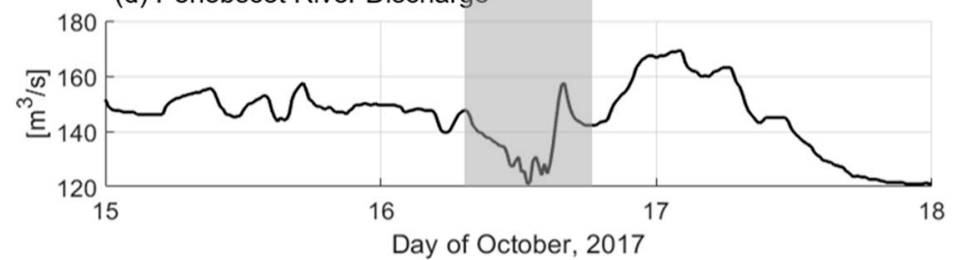

Figure 2. (a) Water level at Castine from mean sea level, (b) difference between bottom $(25 \mathrm{~m})$ and top $(2 \mathrm{~m})$ density anomalies at the Dice Head buoy, (c) wind speed [black] and wind direction [magenta] at Castine, and (d) Penobscot River discharge at West Enfield, ME. Sampling period is shaded in gray.

\subsection{Hydrodynamics}

\subsubsection{Spatial Variability between Peak Flood and Ebb Tides}

During maximum flood currents (hour 18.5$) u$ reached $1.1 \mathrm{~m} / \mathrm{s}$ subsurface (5 to $15 \mathrm{~m}$ depths) over the channel between stations 1 and 2 (Figure 3a(1)). Streamwise velocities decreased toward station 3 and exhibited a combined lateral and vertical shear typical of channel-shoal interfaces from increased friction (e.g., [17]). Maximum $v(0.2 \mathrm{~m} / \mathrm{s})$ occurred in the upper $5 \mathrm{~m}$ of the water column flowing toward the northwest shoal. $v$ was opposite in direction in the mid to lower water column between stations 1 and 2, creating a counter-clockwise lateral circulation during flood over the channel (Figure 3a(2)). That cell became three-layered nearer to station 2, with an added flow towards the northwest shoal developing on the bottom, indicative of a stratified estuary with curvature-driven lateral flow [41]. The circulation cell became less organized between stations 2 and 3 before reforming again on the extreme southeast shoal with two layers. Depth averaged currents show a similar pattern as $u$, with largest velocities over the channel that gradually decreased moving over the southeast shoal (Figure 3a(3)). 


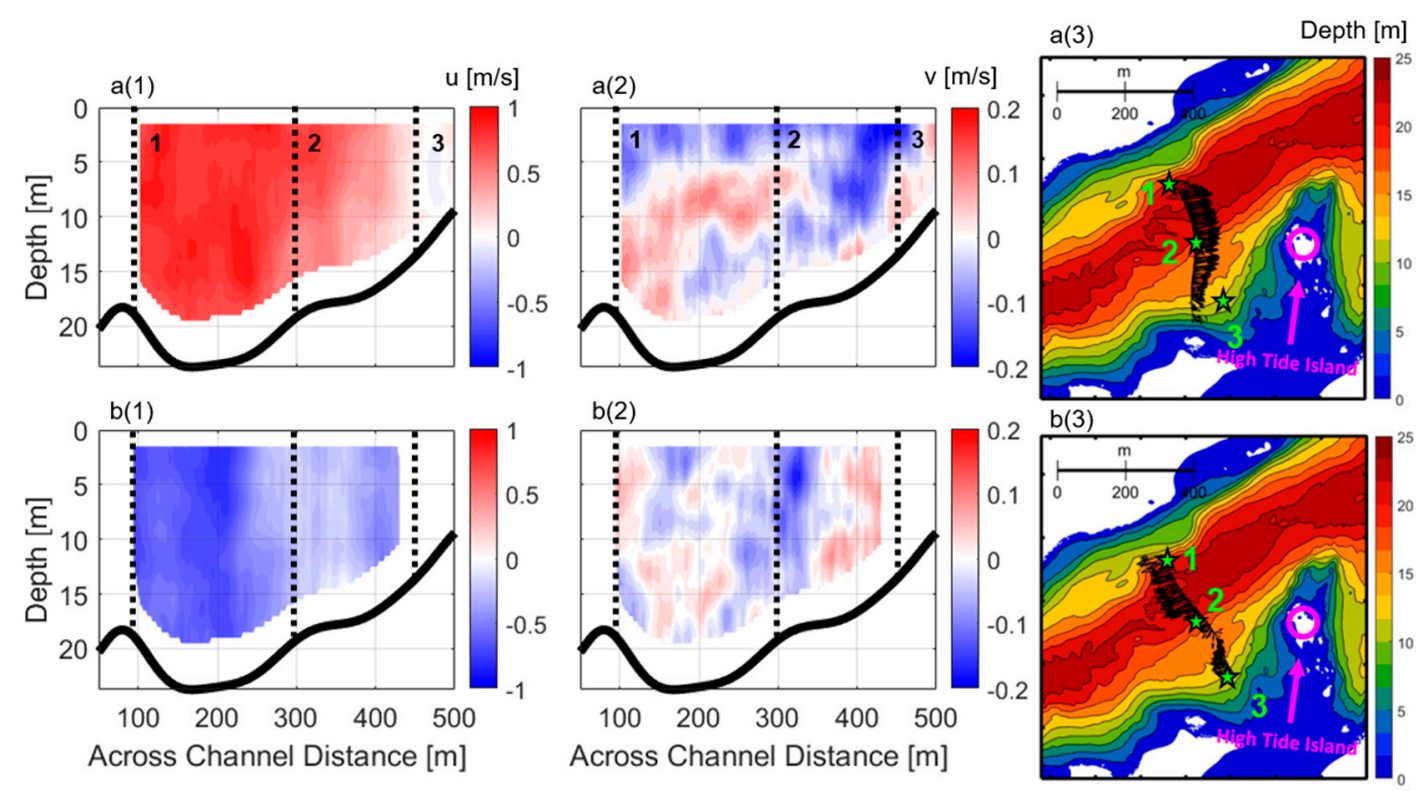

Figure 3. During maximum flood (a panels) and ebb (b panels) tides: Streamwise (column 1) and stream-normal (column 2) velocities with respect to cross-channel distance ( $x$ axis) and depth ( $y$ axis). Positive $u$ is landward, and positive $v$ is to the right. The black dotted lines represent the approximate locations of each MicroCTD sampling station on the transect line. Current vectors for the top $10 \mathrm{~m}$ of the water column are shown on a bathymetric map for each tide (column 3). Each station is noted with a green star and High Tide Island is circled in magenta.

Maximum ebb tide (hour 13) featured a distinctly different velocity structure than flood, noted by a sharp lateral shear in along channel velocities from channel to shoal (Figure 3b(1)). Maximum $u$ on ebb were approximately $1 \mathrm{~m} / \mathrm{s}$ subsurface $(5 \mathrm{~m})$ over the channel and decreased to near $0 \mathrm{~m} / \mathrm{s}$ on the shoal between stations 2 and 3. Unlike $u$ during maximum flood, the ebb currents did not proportionally decrease with bathymetry on the shoal but rather sharply decreased throughout the water column near station 2. Maximum $u$ at station $2(0.3 \mathrm{~m} / \mathrm{s}$ ) occurred subsurface (5 to $10 \mathrm{~m})$. Lateral currents were less organized on ebb than flood, with no clear circulation cells (Figure $3 b(2)$ ). A relatively strong lateral flow $(0.2 \mathrm{~m} / \mathrm{s}$ at surface) towards the channel occurred between stations 2 and 3 . High Tide Island likely contributed to the more unique ebb current structure by advecting water towards the channel (station 2) from the shoal as flow converged in the lee of the headland. An eddy-like feature is present at the same time near station 2, shown by a depth averaged flow that reverses direction relative to the channel (Figure $3 b(3)$ ). Past research has shown flow around headlands and islands can form wakes and eddies which create atypical shear such as that observed here (e.g., [42-44]).

\subsubsection{Stations 1 and 2 Intratidal Analysis}

From middle to end of flood (hours 8 to 10, Figure 4), the water column was defined by significant vertical shears in velocity and increased stratification relative to ebb. The generally near-surface maxima in $u$ (Figure $4 \mathrm{a}$ ) and subsurface $\left(5 \mathrm{~m}\right.$ ) maxima in $v$ (Figure $4 \mathrm{~b}$ ) created enhanced $S^{2}$ values $\left(10^{-3}\right.$ to $\left.10^{-2} \mathrm{~s}^{-2}\right)$ at the surface $(<5 \mathrm{~m})$ at each station on both floods (hours 8-9 and 16-18, Figure $4 \mathrm{c}$ ). $S^{2}$ of relatively high magnitudes $\left(10^{-3}\right.$ to $\left.10^{-2} \mathrm{~s}^{-2}\right)$ were also observed at depth $(8 \mathrm{~m}$ at station 1 and $\sim 15 \mathrm{~m}$ at station 2 ) at the same time. Enhanced stratification coincided with the times of increased vertical shear. Density maxima $\left(1023.7 \mathrm{~kg} / \mathrm{m}^{3}\right)$ for the tidal cycle occurred at depth $15-20 \mathrm{~m}$, while minima $\left(1023.1 \mathrm{~kg} / \mathrm{m}^{3}\right)$ were at the surface $(<5 \mathrm{~m})$ during flood (hours 8-9 and 16-18 in Figure $4 \mathrm{~d}$ ), indicating a saltier mass of water entered the Bagaduce River at depth on flood, encompassing much of the water column, while fresher water was at the surface. Stratification, represented by $N^{2}$, increased during flood at the interface $(7-10 \mathrm{~m})$ between the salty water at depth and fresher water at surface $\left(10^{-3.5}\right.$ to $10^{-3} \mathrm{~s}^{-1}$ at stations 1 and 2, respectively in Figure 4e), indicative of the more stratified water 
mass moving in from the Penobscot River on flood. During the morning flood, a top-to-bottom density difference of $2.7 \mathrm{~kg} / \mathrm{m}^{3}$ from surface to bottom existed in the Penobscot River, a maximum for the day (day 16.4 in Figure 2b). The ebb-tide stratification also featured lateral variability, with stronger $N^{2}$ in the deeper channel at station 2 relative to the shallower, near-shoal, station 1.

(a) Streamwise Velocity, $u$

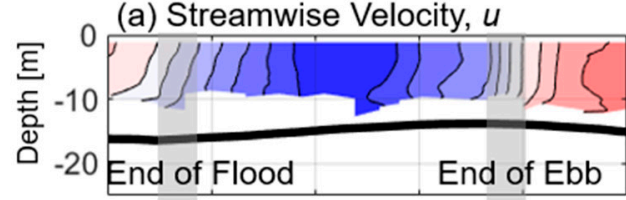

(b) Stream-normal Velocity, $v$

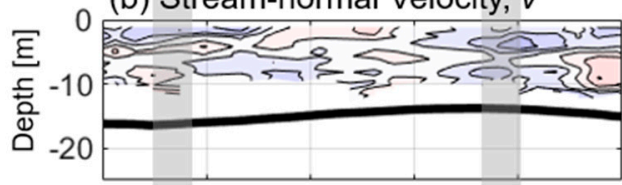

(c) Squared Vertical Shear, S²

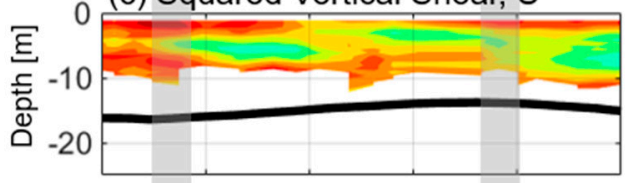

(d) Density, $\rho$

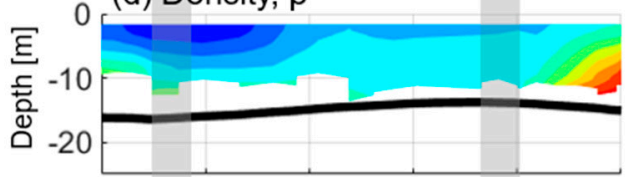

(e) Buoyancy Frequency, $N^{2}$

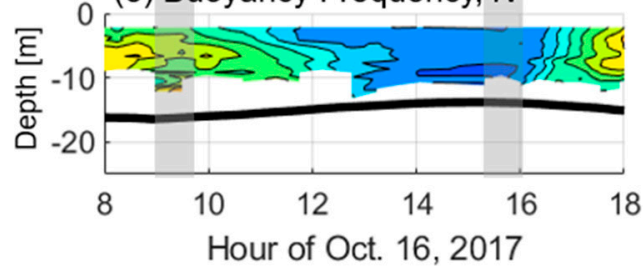

[m s-1]

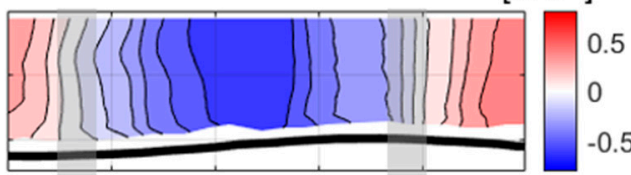

[m s $\left.\mathrm{m}^{-1}\right]$

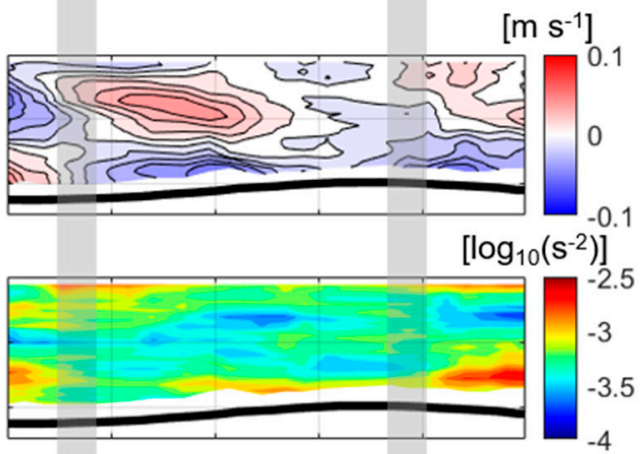

$\left[\mathrm{kg} / \mathrm{m}^{3}\right]$

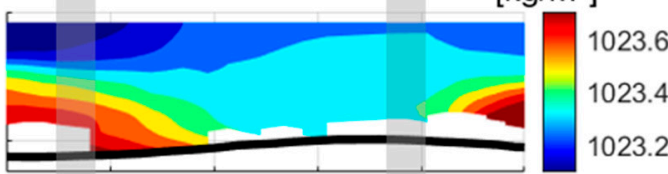

1023.2

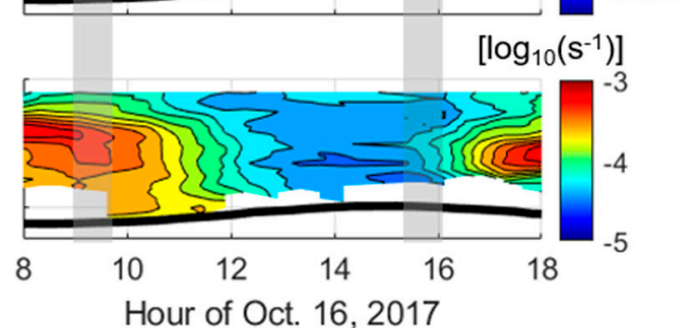

Hour of Oct. 16, 2017

Figure 4. At stations 1 (left panels) and 2 (right panels): (a) Streamwise velocity. Positive values represent flow into the estuary; negative represent outflow. (b) Stream-normal velocity. Positive depicts flow directed right (when looking landward) and negative is flow directed left. (c) Squared vertical shear, $S^{2}$. (d) Density, $\rho$. (e) Buoyancy frequency, $N^{2}$. Hour of 16 October 2017 is the $x$ axis of each subplot, and depth is the $y$ axis. Panels (c) and (e) show $\log _{10}$ values. Shaded boxes represent the end of flood and ebb tides.

Vertical shears in horizontal currents maintained near surface on ebb at both stations which coincided with a decrease in stratification and a more disorganized lateral circulation pattern from eddy development. $S^{2}$ remained elevated near the surface at both stations $\left(10^{-3}\right.$ to $\left.10^{-2} \mathrm{~s}^{-2}\right)$ through most of ebb but featured more temporal variability at depth with minima as low as $10^{-4} \mathrm{~s}^{-2}$ (hours 12 to 14, Figure 4c). At the same time, a defined three-layer lateral circulation cell at station 2 formed during the beginning of ebb with flow directed towards station 3 at mid depths (5 to $10 \mathrm{~m}$ ) and toward station 1 at the surface and bottom. The cell became disorganized as ebb progressed (hours 10 to 14 in Figure $4 b$ ). A similar cell with weaker currents maintained at station 1 throughout ebb (Figure 4a). Depth averaged $v$ at station 2 was non-zero during this time (not shown), indicating circulation may have become disrupted by helical flow (eddy) which formed in the lee of High Tide Island. As the circulation cell diminished, $N^{2}$ decreased $\left(10^{-3} \mathrm{~s}^{-1}\right.$ at hour 9.5 to $10^{-5} \mathrm{~s}^{-1}$ at hours 13 to 16 in Figure $\left.4 \mathrm{e}\right)$ and the density profile at each station became more homogenous (increase to $1023.3 \mathrm{~kg} / \mathrm{m} 3$ at surface, decrease to 1023.4 at depth in Figure 2d). The maintenance of near-surface shears, particularly at station 
2, likely was influenced by the coinciding decrease in stratification and eddy formation disrupting the horizontal currents.

\subsubsection{Dissipation and Mixing}

Vertical mixing was generally limited on the flood tide from increased stratification. Contours of $R i$ during flood show values near or larger than 0.25 at most depths, indicating stratification likely suppressed shear-driven vertical mixing (Figure 5a). Conditions favorable for shear-driven mixing $(R i<0.25)$ occurred at depths less than $5 \mathrm{~m}$ (station 1 ) and coincided with the enhanced near-surface shear outlined in Section 3.2.2. $\varepsilon, A_{z}$, and $K_{z}$ all were small relative to the rest of the tidal cycle $(\varepsilon$ : $10^{-8} \mathrm{~W} \cdot \mathrm{kg}^{-1} ; A_{z}: \sim 10^{-4} \mathrm{~m}^{2} \cdot \mathrm{s}^{-1} ; K_{z}: 10^{-5} \mathrm{~m}^{2}$ ) at both stations (Figure $5 \mathrm{~b}-\mathrm{d}$ ). Turbulent eddies were suppressed by the stratified water column, indicated by Ozmidov length scales [45], $L_{0}=\sqrt{\frac{\epsilon}{N^{3}}}$, that were less than $0.5 \mathrm{~m}$.

(a) Ri/0.25

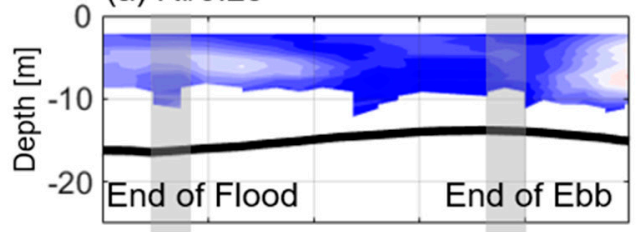

(b) TKE Dissipation Rate, $\varepsilon$

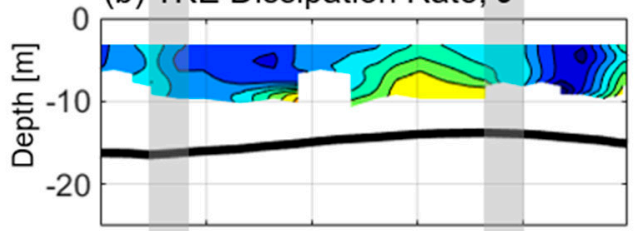

(c) Vertical Eddy Diffusivity, $K_{z}$

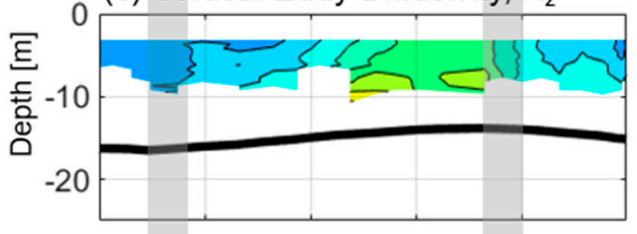

(d) Vertical Eddy Viscosity, $A_{z}$

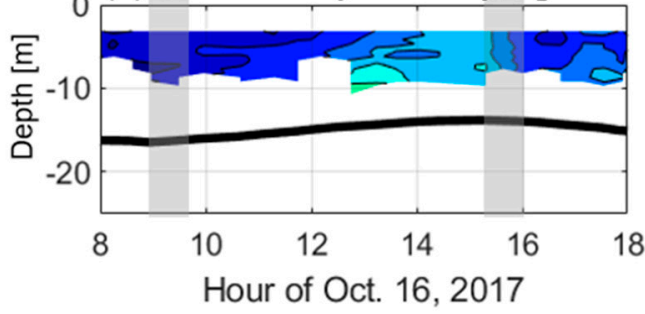

$\left[\log _{10}(\mathrm{Ri} / 0.25)\right]$
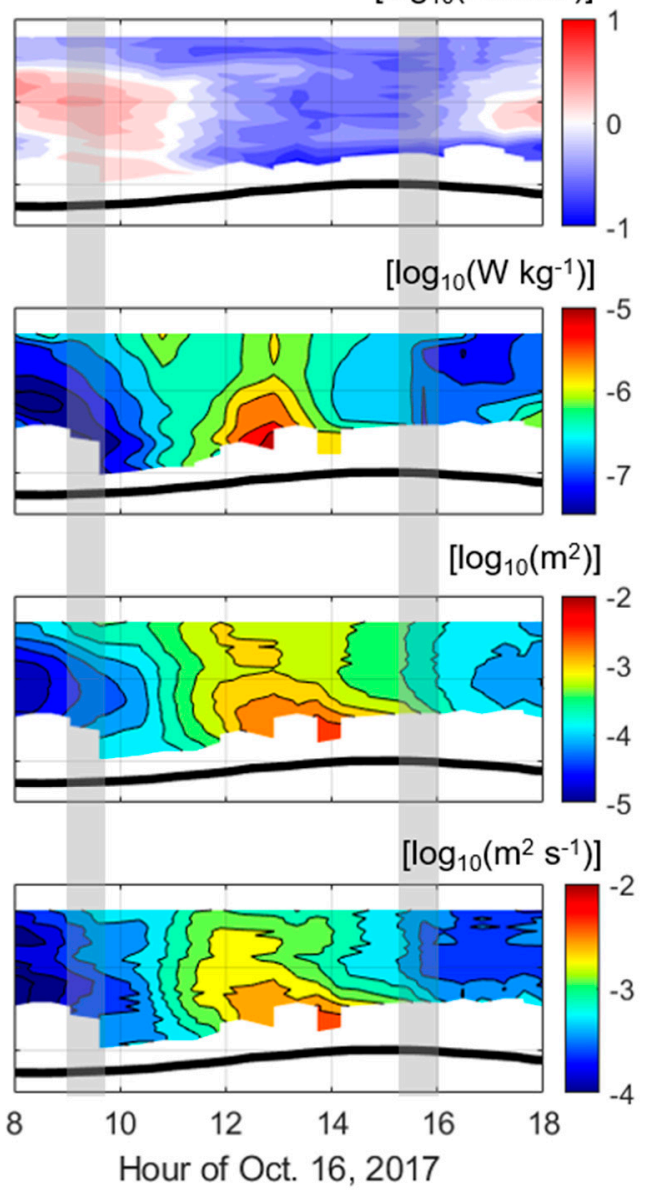

Figure 5. At stations 1 (left panels) and 2 (right panels): (a) Gradient Richardson number, Ri, divided by 0.25 (values less than 0 indicate $R i<0.25$ ). (b) TKE dissipation rate, $\varepsilon$. (c) Vertical eddy diffusivity, $K_{z}$. (d) Vertical eddy viscosity, $A_{z}$. Hour of 16 October 2017 is the $x$ axis of each subplot, and depth is the $y$ axis. All panels show $\log _{10}$ values. Shaded boxes represent the end of flood and ebb tides.

Richardson numbers on ebb at both stations indicated vertical mixing was expected to follow stratification patterns outlined above. Conditions were favorable for shear to overcome the stratifying effects of buoyancy at the surface $(R i<0.25$ at depth $<5 \mathrm{~m})$ throughout ebb, with less agreeable conditions $(R i>0.25)$ at depth at the start of ebb (depth $>5 \mathrm{~m}$ at hours 9.5 to 11$)$ which changed to more favorable $(R i<0.25)$ as the water column density homogenized by peak ebb (Figure $5 a)$. Large $\varepsilon$, $A_{z}$, and $K_{z}$ values for the tidal cycle occurred during ebb, with bottom-generated turbulence increasing 
then maximizing $\epsilon\left(10^{-5} \mathrm{~W} \cdot \mathrm{kg}^{-1}\right), A_{z}\left(10^{-2} \mathrm{~m}^{2} \cdot \mathrm{s}^{-1}\right)$, and $K_{z}\left(10^{-2} \mathrm{~m}^{2}\right)$ at both stations (though largest at station 2 ) and extending into the mid depths ( $10 \mathrm{~m}$ at hours 12 to 14 , Figure $5 \mathrm{~b}-\mathrm{d}$ ) as the largest eddy sizes increased to $L_{O}=5 \mathrm{~m}$.

Near-surface $\varepsilon$ and $K_{z}$ were identified at station 2 ( $<10 \mathrm{~m}$ depth during hours 11 to 13 , Figure $5 \mathrm{~b}, \mathrm{c}$ ), decoupled from the bottom. The increased $\varepsilon$ was linked to the enhanced vertical mixing $\left(K_{Z}\right)$ also decoupled from the bottom in the same regions $\left(\varepsilon: 10^{-6} \mathrm{~W} \cdot \mathrm{kg}^{-1}\right.$ and $\left.K_{z}: 10^{-2.5} \mathrm{~m}^{2}\right)$. Although $R i$ values suggested mixing-favorable conditions near the surface throughout the tidal cycle, these data show that enhanced mixing only formed near the surface on ebb.

\section{Discussion}

Bottom-generated vertical mixing was enhanced on ebb as compared to flood because of the interaction between the Penobscot and Bagaduce Rivers. The largest vertical mixing occurred near the bottom during maximum ebb, but moderate $\epsilon$ and $K_{z}$ were identified near the surface $(<10 \mathrm{~m}$ depth) as well. Recent work has identified lateral circulation (or streamwise vorticity) induced mechanisms can enhance near-surface mixing at channel-shoal interfaces (e.g., [17,18]), but the observations in this study do not reflect a two-layer lateral circulation throughout the tidal cycle. Therefore, another mechanism was investigated which can both explain the prevention of lateral circulation and appearance of episodic near-surface mixing during ebb: an eddy induced by a headland.

\subsection{Eddy Formation}

Eddies can form behind islands and headlands, creating strongly asymmetric flow fields throughout a tidal cycle (e.g., [42,43]). Eddies can be identified by concentrated vorticity in areas of flow separation, where streamlines break away from the coast and carry high vorticity fluid from lateral boundaries into the interior of the flow field [43]. These eddies are reflected in the vertical component of vorticity:

$$
\omega_{z}=\frac{\partial v}{\partial x}-\frac{\partial u}{\partial y}
$$

which is often used to identify eddy formation by tidal flow, with stronger vertical vorticity indicative of stronger eddy development (e.g., [46,47]). The first term in Equation (10), the streamwise variation in lateral flow, was not possible to calculate with the data collected, and so the second term, the lateral variation in streamwise flow, was used as a proxy for vertical vorticity.

Eddy development was identified during ebb tide in the current velocity data. During ebb, nonlinear flow was evident over the study area as spatially averaged streamwise velocities episodically oscillated near $0 \mathrm{~m} / \mathrm{s}$ (hour 12, Figure 6a) even as $u$ within the main channel approached $1 \mathrm{~m} / \mathrm{s}$ (Figure 3b). Also, the lateral circulation diminished at approximately the same time (hour 12, Figure $4 b$ ). $\frac{\partial u}{\partial y}$ exhibited the largest magnitudes over the channel shoal interface around station $2\left(0.05 \mathrm{~s}^{-1}\right.$ at 200 to $400 \mathrm{~m}$ in Figure $6 \mathrm{~b}$ ) during ebb, and depth averaged currents reversed direction over the channel-shoal interface near station 2 (Figure 6c). The depth averaged current vectors show a cross section typical of a headland-produced eddy [43], with a clockwise flow produced in the lee of High Tide Island directing flow from the channel, over the shoal, then back into the channel. Eddy development was most pronounced during the middle of ebb tide (hours 11 to 14, not shown) as the eddy likely needed time to spin-up and spin-down on either side of slack tides [48]. 

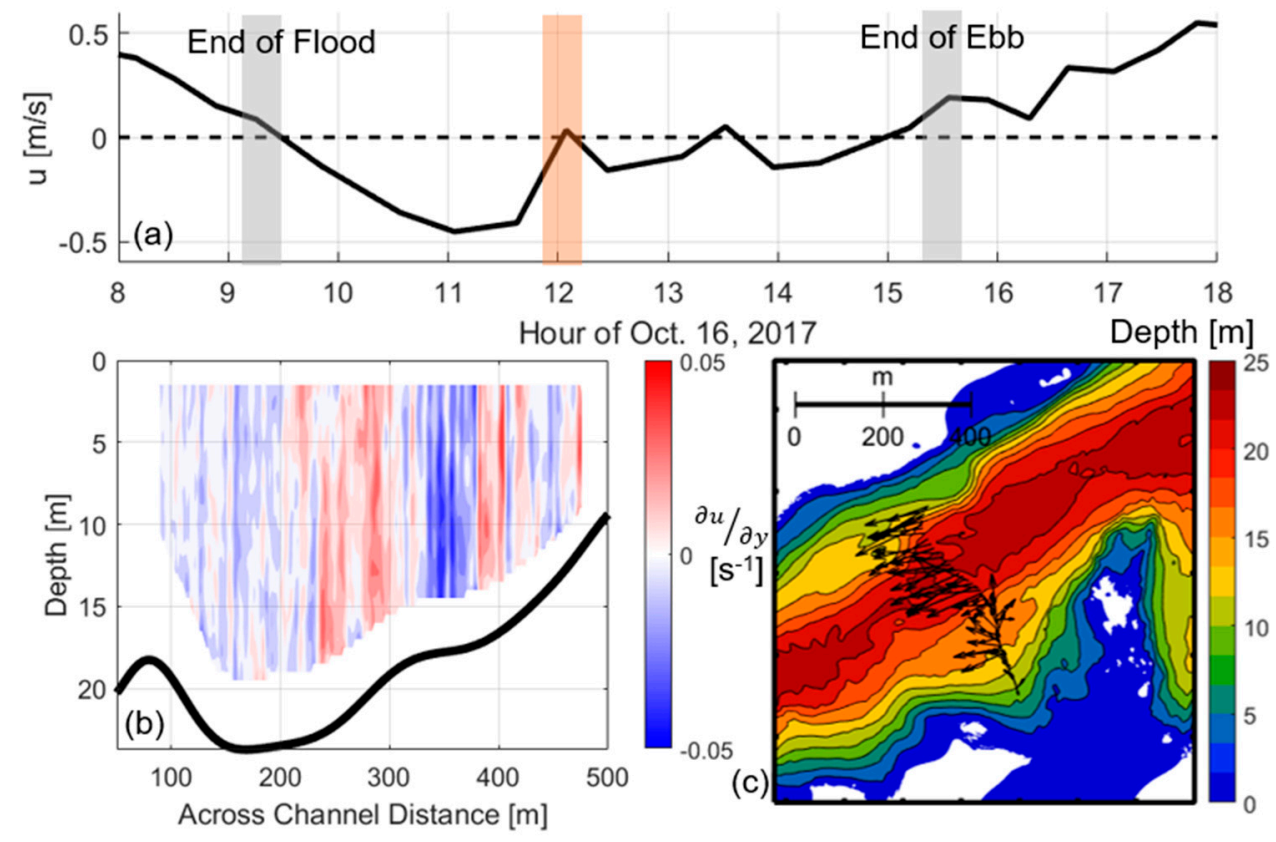

Figure 6. At station 2: (a) Depth-averaged along-channel velocity at station 2 over the tidal cycle. Grey boxes indicate the end of each tidal phase and the orange box indicates the time of a transect during maximum ebb, shown in (b,c). (b) $\frac{\partial u}{\partial y}$ varying across channel ( $x$-axis) with depth ( $y$-axis) and (c) depth averaged current vectors over bathymetry for the transect noted. $\frac{\partial u}{\partial y}$ was smoothed over two depth bins $(1 \mathrm{~m})$ and six across-channel bins $(12 \mathrm{~m})$ to highlight broad trends.

The eddy and flow near the eddy in this study can be described by non-dimensional numbers which place the observations in context of other systems. In oscillatory, viscous flow around a headland-like feature, the frictional Reynold's number [49] $\left(R e=\frac{H}{C_{d} a}\right.$, where $H$ is water depth, $C_{d}$ is the drag coefficient [0.003], and $a$ is the alongshore extent of the headland) and Keulegan-Carpenter number [50] ( $K C=\frac{V T}{a}$, with $V$ being the tidal velocity and $T$ the oscillatory period) are two important parameters which describe the importance of friction and local accelerations to advection in the eddy flow. In our case, using the mean depth at station $2(H=20 \mathrm{~m})$, approximate headland length $(a=$ $200 \mathrm{~m}$ ), maximum tidal flow of $0.8 \mathrm{~m} / \mathrm{s}$, and an oscillatory period $(T=8 \mathrm{~min}$ ) estimated from the Strouhal number $\left(S t=0.198\left(1-\frac{19.7}{R e}\right)[51]\right)$, the frictional Reynolds number is 33 and $K C=2$. According to these values, the eddy development behind High Tide Island is controlled by $K C$ (advection) and so vorticity is likely transported away from the boundary layer and eddy. Friction is considered weak, and so eddy development is strongly dependent on tidal current magnitudes which reform eddies every half tide [43]. This is a typical case for a strongly tidal system with highly variable flow patterns as outlined in Signell and Geyer (1991), although their model was representative of a larger-scale headland $(5-10 \mathrm{~km})$.

\subsection{Eddy-Induced Near-Surface Mixing}

Previous studies have shown that streamwise vorticity (lateral circulation) can advect slower water from a shoal over faster water in the channel and enhance vertical shears in horizontal currents and mixing near surface [17]. What is yet to be determined is whether vertical vorticity from eddies can function in a similar way: advect slower water from behind a headland over faster channel water and produce near-surface mixing. To investigate this, lateral gradients in streamwise flow (our proxy for $\omega_{z}$ ) over all ebb tide measurements (hours 9.5 to 15 in Figure 6) were bin averaged and compared to vertical shears in streamwise flow to determine whether regions of eddy development could be linked to shear-driven vertical mixing. For lateral shear magnitudes less than $0.2 \mathrm{~s}^{-1}$, vertical shear in $u$ remained nearly constant at $0.08 \mathrm{~s}^{-1}$ (Figure 7). For larger $\frac{\partial u}{\partial y}\left(>0.20 \mathrm{~s}^{-1}\right.$ ), typical of those seen in 
the vicinity of station 2 where eddy development occurred, $\frac{\partial u}{\partial z}$ magnitudes sharply increase to larger than $0.14 \mathrm{~s}^{-1}$ (Figure 7). Quantitatively, Figure 7 shows that where the largest $\frac{\partial u}{\partial y}$ occur on ebb, the largest $\frac{\partial u}{\partial z}$ are also likely to occur. Qualitatively, this is outlined in Figure 8, which depicts how eddy development during ebb tide over the channel-shoal interface in the lee of High Tide Island carried the relatively slower near-surface water from the shoal over the relatively fast-moving fluid in the channel. The faster water beneath slower surface flow was observed during ebb at station 2 (Figure 3), outlining this further. As this process occurred, magnitudes of $\frac{\partial u}{\partial y}$ were spatially and temporally large for the tidal cycle, as vorticity and vertical shear were added to the streamwise flow. The increase in lateral and vertical shear in $u$ occurring over the channel-shoal interface then produced the enhanced near-surface vertical mixing observed at station 2 (Figure 5).

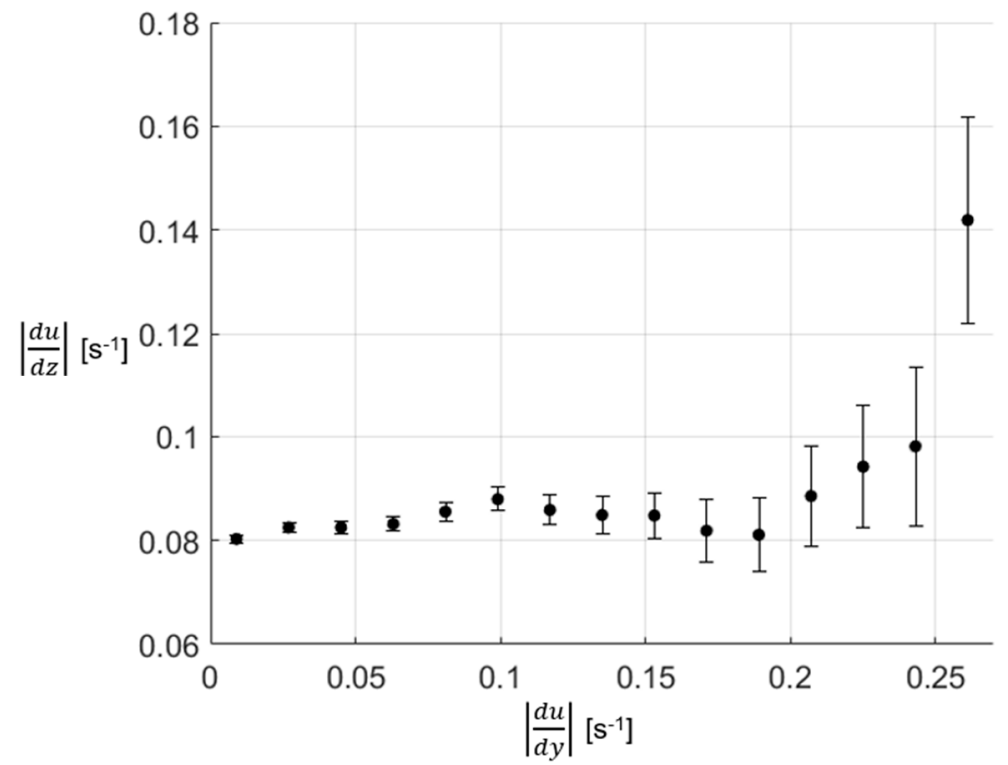

Figure 7. Absolute value of lateral shear in streamwise velocity $\left(\frac{\partial u}{\partial y}\right)$ on $x$-axis relative to the absolute value of vertical shear of $u\left(\frac{\partial u}{\partial z}\right)$ on the $y$-axis during ebb tide. Values are bin averaged according to $\frac{\partial u}{\partial y}$ with error bars representing the standard error of all $\frac{\partial u}{\partial z}$ points in each bin.

Station 2 was the only location on the transect line where near-surface mixing (decoupled from the bottom layer) was observed and that mixing was constrained to the few hours around peak ebb tide (hours 11 to 14 in Figure 5). Mixing at stations 1 and 3 (not shown) was bottom generated and rose through the water column in a similar fashion to station 2 on ebb (Figure 5). The lack of near-surface mixing at those stations ( 1 and 3 ) further illustrates the small spatial extent of mixing-prone conditions constrained near the eddy produced by the upstream island. Further, the temporal constraint of the near-surface mixing to only a few hours during peak ebb is likely due to the transient nature of eddies [43,52]. It is very likely that the eddy was moving translationally, or sampling simply did not occur within it on every transect. 


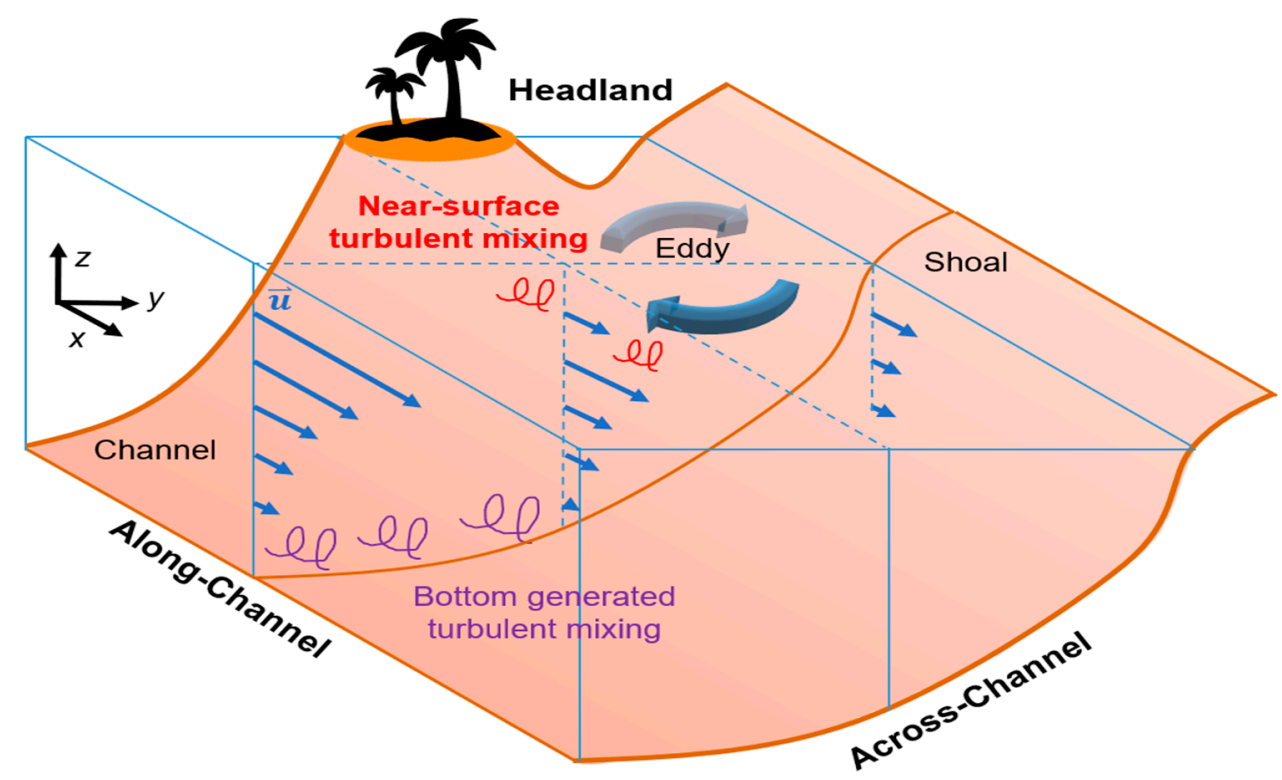

Figure 8. Conceptual diagram showing mechanisms creating enhanced turbulent mixing on ebb tide. The view is looking into the estuary from the sea. Near-surface mixing lies where increased lateral shear overlaps with increased vertical shear in streamwise currents. Relative direction and magnitude of streamwise currents are shown as blue arrows, the eddy as blue curved arrows, bottom-generated turbulent mixing as purple squiggles, and near-surface mixing as red squiggles.

The observations from this study show vertical vorticity, represented by lateral shears in $\mathrm{u}$, created from eddies can enhance near-surface vertical mixing over channel-shoal interfaces. Until now, no work has identified near-surface mixing from lateral processes unrelated to streamwise vorticity. This work is the first to highlight the role of headlands in inducing vertical mixing in regions with channel-shoal morphology in low inflow estuaries. This transient mechanism was identified during a single tidal cycle survey. In order to understand the prevalence and influence of eddy generated mixing on momentum and transport, more tidal cycle surveys are necessary. Nonetheless, this work does indicate that near-surface mixing should be expected downstream of a headland near channel-shoal bathymetry in a macrotidal, low inflow system, typical of many Maine estuaries. For example, former research has identified the tendency for enhanced turbulence to occur near headlands $[53,54]$ and near-surface mixing has been observed in other estuaries with eddies near channel-shoal bathymetry [22,30,55]. Those referenced studies observed near-surface mixing in headland-induced eddies were in the Damariscotta River, Maine, another macrotidal, low-inflow estuary. Although those authors state that determining the process causing the mixing was outside the scope of their work, they do identify near-surface mixing $\left(A_{Z}: 10^{-2.4} \mathrm{~m}^{2} / \mathrm{s}\right)$ with minimal fortnightly variability in the headland-induced eddy [22]. The results of the current work demonstrate that the mechanism causing near-surface mixing in headland-induced eddies is the interaction of the eddy with channel-shoal bathymetry, which enhances shear near the surface and generates wall-free turbulence. In partially mixed systems that feature stronger stratification during certain phases of the tide, we export more fortnightly variability in mixing in these headland-induced eddies. An important area of future research is to understand the fortnightly and seasonal variability of mixing in headland-induced eddies in systems with more significant stratification. Other work has determined that form drag (the force created by pressure differentials across an obstacle in a flow field) can create mixing on the leeward side of headlands [56]. Mixing due to form drag is more prone to occur in the middle to near-bottom of the water column, though, unlike the observations presented here.

Complex estuary morphology with frequent headlands and channel-shoal bathymetry is common in mid-latitude, glacially carved estuaries such as those of Maine, southeast Canada, and the Pacific Northwest of the United States and Canada. The complicated shapes of these systems and often strong 
tides make them prone to nonlinear hydrodynamics, such as eddies [22]. The results of this work show that eddies can also be a mechanism for asymmetric mixing within these estuaries, both spatially and temporally, which likely modifies the traditional subtidal flow regimes and transport defined by tidal straining and ESCO circulation. Future work is needed to make more concrete connections between ESCO and asymmetric near-surface mixing, but the observations of the present study provide another mechanism which may create that connection.

\section{Conclusions}

The objectives of this work were to determine the intratidal and lateral variability in mixing in a macrotidal, low-inflow estuary and diagnose the forcing mechanisms responsible for mixing decoupled from the bottom boundary. The main messages were that elevated mixing can occur on ebb tide relative to flood from velocity shears destabilizing a more homogenous water column on ebb when salty water at depth and fresh water near surface is flushed from the estuary. The mixing was mainly bottom generated and was uniform across the estuary. Also, near-surface vertical mixing was created by eddies induced by along channel variations in bathymetry from features like headlands. Strong turbulence $\left(10^{-6} \mathrm{~W} \cdot \mathrm{kg}^{-1}\right)$ was observed in the top $10 \mathrm{~m}$ of the water column at a channel-shoal interface location during ebb tide. The turbulence coincided with elevated mixing $\left(K_{z}: 10^{-3} \mathrm{~m}^{2}\right.$; $A_{z}: 10^{-2.5} \mathrm{~m}^{2} / \mathrm{s}$ ), which was decoupled from bottom-generated turbulence. The enhanced mixing only occurred in the immediate vicinity of an eddy created by an upstream island, creating a lateral asymmetry in near-surface turbulence. Former work has attributed lateral processes from buoyancy and current shears to the creation of mixing decoupled from the bottom. These results present new evidence that near-surface turbulent mixing can develop from eddies produced by along-channel bathymetric features.

Author Contributions: Conceptualization, K.H.; methodology, K.H.; formal analysis, P.S.; investigation, P.S. and K.H.; resources, P.S. and K.H.; data curation, P.S.; writing-original draft preparation, P.S.; writing-review and editing, P.S. and K.H.; visualization, P.S.; supervision, K.H.; project administration, K.H.; funding acquisition, K.H. All authors have read and agreed to the published version of the manuscript.

Funding: This research was funded by National Science Foundation Award IIA-1355457: Maine EPSCoR; The Nexus of Coastal Social-Environmental Systems and Sustainable Ecological Aquaculture.

Acknowledgments: The authors would like to thank Elliot Huguenard, Kris Bears, Leon Cortes Garcia, Sohaib Alahmed, Rachel Chambers, and Biao Geng for help with data collection. The authors would also like to thank Joe Kelley and Cody Barnett for providing bathymetry data in the Bagaduce River, and three anonymous reviewers for their constructive comments on the original manuscript.

Conflicts of Interest: The authors declare no conflict of interest.

\section{References}

1. Geyer, W.R.; MacCready, P. The Estuarine Circulation. Annu. Rev. Fluid Mech. 2014, 46, 175-197. [CrossRef]

2. Hansen, D.V.; Rattray, M. Gravitational circulation in straits and estuaries. J. Mar. Res. 1965, 23, $104-122$.

3. Pritchard, D.W. The dynamic structure of a coastal plain estuary. J. Mar. Res. 1956, 15, 33-42.

4. Partch, E.N.; Smith, J.D. Time dependent mixing in a salt wedge estuary. Estuar. Coast. Mar. Sci. 1978, 6, 3-19. [CrossRef]

5. Ianniello, J.P. Tidally induced residual currents in estuaries of variable breath and depth. J. Phys. Ocean. 1979, 9, 962-974. [CrossRef]

6. Jay, D.A.; Dungan Smith, J. Circulation, density distribution and neap-spring transitions in the Columbia River Estuary. Prog. Oceanogr. 1990, 25, 81-112. [CrossRef]

7. Jay, D.A. Green's law revisited: Tidal long-wave propagation in channels with strong topography. J. Geophys. Res. 1991, 96, 20585-20598. [CrossRef]

8. Simpson, J.H.; Brown, J.; Matthews, J.; Allen, G. Tidal straining, density currents, and stirring in the control of estuarine stratification. Estuaries 1990, 13, 125-132. [CrossRef]

9. Jay, D.A.; Musiak, J.D. Particle trapping in estuarine tidal flows. J. Geophys. Res. 1994, 99, $20445-20461$. [CrossRef] 
10. Dijkstra, Y.; Schuttelarrs, H.; Burchard, H. Generation of exchange flows in estuaries by tidal and graviational eddy viscosity-shear covariance. J. Geophys. Res. Ocean. 2017, 122, 4217-4237. [CrossRef]

11. Dyer, K.R. Tidally generated estuarine mixing processes. In Hydrodynamics of Estuaries: Volume I Estuarine Physics; CRC Press: Boca Raton, FL, USA, 2018; ISBN 9781351081702.

12. Peters, H. Spatial and temporal variability of turbulent mixing in an estuary. J. Mar. Res. 1999, 57, 805-845. [CrossRef]

13. Rippeth, T.P.; Fisher, N.R.; Simpson, J.H. The cycle of turbulent dissipation in the presence of tidal straining. J. Phys. Oceanogr. 2001, 31, 2458-2471. [CrossRef]

14. Scully, M.E.; Geyer, W.R. The Role of Advection, Straining, and Mixing on the Tidal Variability of Estuarine Stratification. J. Phys. Oceanogr. 2012, 42, 855-868. [CrossRef]

15. Burchard, H.; Hetland, R.D. Quantifying the Contributions of Tidal Straining and Gravitational Circulation to Residual Circulation in Periodically Stratified Tidal Estuaries. J. Phys. Oceanogr. 2010, 40, 1243-1262. [CrossRef]

16. New, A.L.; Pingree, R.D. Evidence for internal tidal mixing near the shelf break in the Bay of Biscay. Deep Sea Res. Part A 1990, 37, 1783-1803. [CrossRef]

17. Collignon, A.G.; Stacey, M.T. Turbulence Dynamics at the Shoal-Channel Interface in a Partially Stratified Estuary. J. Phys. Oceanogr. 2013, 43, 970-989. [CrossRef]

18. Huguenard, K.D.; Valle-Levinson, A.; Li, M.; Chant, R.J.; Souza, A.J. Linkage between lateral circulation and near-surface vertical mixing in a coastal plain estuary. J. Geophys. Res. Ocean. 2015, 120, 4048-4067. [CrossRef]

19. Ross, L.; Huguenard, K.; Sottolichio, A. Intratidal and Fortnightly Variability of Vertical Mixing in a Macrotidal Estuary: The Gironde. J. Geophys. Res. Ocean. 2019, 124, 2641-2659. [CrossRef]

20. Peters, H. Observations of Stratified Turbulent Mixing in an Estuary: Neap-to-spring Variations During High River Flow. Estuar. Coast. Shelf Sci. 1997, 45, 69-88. [CrossRef]

21. Fernández-Castro, B.; Gilcoto, M.; Naveira-Garabato, A.C.; Villamaña, M.; Graña, R.; Mouriño-Carballido, B. Modulation of the Semidiurnal Cycle of Turbulent Dissipation by Wind-Driven Upwelling in a Coastal Embayment. J. Geophys. Res. Ocean. 2018, 123, 4034-4054. [CrossRef]

22. Lieberthal, B.; Huguenard, K.; Ross, L.; Bears, K. The Generation of Overtides in Flow Around a Headland in a Low Inflow Estuary. J. Geophys. Res. Ocean. 2019, 124, 955-980. [CrossRef]

23. Berleant, A. Culture and Aquaculture of Bagaduce River Draws 250 to DMR Meeting. Castine Patriot. 2014. Available online: http://weeklypacket.com/news/2014/may/8/culture-and-aquaculture-of-bagaduce-riverdraws-25/\#.XienDyMRVPY (accessed on 29 November 2019).

24. Dudley, R. Regression Equations for Monthly and Annual Mean and Selected Percentile Streamflows for Ungaged Rivers in Maine. U.S. Geol. Surv. Water-Resour. Investig. Rep. 2015, 2015-5151. [CrossRef]

25. Spicer, P.; Huguenard, K.; Ross, L.; Rickard, L.N. High-Frequency Tide-Surge-River Interaction in Estuaries: Causes and Implications for Coastal Flooding. J. Geophys. Res. 2019. [CrossRef]

26. Rockwell Geyer, W.; Ralston, D.K. A mobile pool of contaminated sediment in the Penobscot Estuary, Maine, USA. Sci. Total Environ. 2018, 612, 694-707. [CrossRef]

27. Spicer, P. Tide and Storm Surge Dynamics in Estuaries of Variable Morphology; University of Maine: Orono, ME, USA, 2019.

28. Hodgkins, G. Estimating the Magnitude of Peak Flows for Streams in Maine for Selected Recurrence Intervals. U.S. Geol. Surv. Water-Resour. Investig. Rep. 1999, 99-4008. [CrossRef]

29. Dudley, R. Estimating Monthly, Annual, and Low 7-Day, 10-Year Streamflows for Ungaged Rivers in Maine. U.S. Geol. Surv. Water-Resour. Investig. Rep. 2004, 2004-5026. [CrossRef]

30. Huguenard, K.; Bears, K.; Lieberthal, B. Intermittency in Estuarine Turbulence: A Framework toward Limiting Bias in Microstructure Measurements. J. Atmos. Ocean. Technol. 2019, 36, 1917-1932. [CrossRef]

31. Joyce, T.M. On In Situ "Calibration" of Shipboard ADCPs. J. Atmos. Ocean. Technol. 1989, 6, 169-172. [CrossRef]

32. Rhoads, B.L.; Kenworthy, S.T. Time-averaged flow structure in the central region of a stream confluence. Earth Surf. Process. Landforms 1998, 23, 171-191. [CrossRef]

33. Lueck, R.G.; Wolk, F.; Yamazaki, H. Oceanic velocity microstructure measurements in the 20th century. J. Oceanogr. 2002, 58, 153-174. [CrossRef] 
34. Goodman, L.; Levine, E.R.; Lueck, R.G. On measuring the terms of the turbulent kinetic energy budget from an AUV. J. Atmos. Ocean. Technol. 2006, 23, 977-990. [CrossRef]

35. Stips, A. Dissipation measurement: Theory. In Marine Turbulence: Theories, Observations and Models; Baumert, H.Z., Simpson, J.H., Sundermann, J., Eds.; Cambridge University Press: Cambridge, UK, 2005; pp. 115-126.

36. Kay, D.J.; Jay, D.A. Interfacial mixing in a highly stratified estuary 1. Characteristics of mixing. J. Geophys. Res. C 2003, 108. [CrossRef]

37. Osborn, T.R. Estimates of the Local Rate of Vertical Diffusion from Dissipation Measurements. J. Phys. Oceanogr. 1980, 10, 83-89. [CrossRef]

38. Miles, J.W. On the stability of heterogeneous shear flows. J. Fluid Mech. 1961, 10, 496-508. [CrossRef]

39. Geyer, W.R.; Scully, M.E.; Ralston, D.K. Quantifying vertical mixing in estuaries. Environ. Fluid Mech. 2008, 8, 495-509. [CrossRef]

40. Tjernstrom, M. Turbulence length scales in stably stratified free shear flow analyzed from slant aircraft profiles. J. Appl. Meteorol. 1993, 32, 948-963. [CrossRef]

41. Nidzieko, N.J.; Hench, J.L.; Monismith, S.G. Lateral circulation in well-mixed and stratified estuarine flows with curvature. J. Phys. Oceanogr. 2009, 39, 831-851. [CrossRef]

42. Pattiaratchi, C.; James, A.; Collins, M. Island wakes and headland eddies: A comparison between remotely sensed data and laboratory experiments. J. Geophys. Res. Ocean. 1987, 92, 783-794. [CrossRef]

43. Signell, R.P.; Geyer, W.R. Transient eddy formation around headlands. J. Geophys. Res. Ocean. 1991, 96, 2561-2575. [CrossRef]

44. Dong, C.; McWilliams, J.C.; Shchepetkin, A.F. Island wakes in deep water. J. Phys. Oceanogr. 2007, 37, 962-981. [CrossRef]

45. Smyth, W.D.; Moum, J.N. Length scales of turbulence in stably stratified mixing layers. Phys. Fluids 2000, 12, 1327-1342. [CrossRef]

46. Zimmerman, J.T.F. Topographic Generation of Residual Circulation by Oscillatory (Tidal) Currents. Geophys. Astrophys. Fluid Dyn. 1978, 11, 35-47. [CrossRef]

47. Robinson, I.S. Tidal vorticity and residual circulation. Deep Sea Res. Part A 1981, 28, 195-212. [CrossRef]

48. Geyer, W.R. Three-dimensional tidal flow around headlands. J. Geophys. Res. 1993, 98, 955-966. [CrossRef]

49. Wolanski, E.; Imberger, J.; Heron, M.L. Island wakes in shallow coastal waters. J. Geophys. Res. 1984, 89, 10553-10569. [CrossRef]

50. Keulegan, G.H.; Carpenter, L.H. Forces on cylinders and plates in an oscillating fluid. J. Res. Natl. Bur. Stand. 1958, 2857, 423-440. [CrossRef]

51. Turbulence: An Introduction for Scientists and Engineers; Choice Review Online; Oxford University Press: Oxford, UK, 2005.

52. Geyer, W.R.; Signell, R. Measurements of tidal flow around a headland with a shipboard acoustic Doppler current profiler. J. Geophys. Res. 1990, 95, 3189-3197. [CrossRef]

53. Stevens, C. Short-term dispersion and turbulence in a complex-shaped estuarine embayment. Cont. Shelf Res. 2010, 30, 393-402. [CrossRef]

54. Thomson, J.; Polagye, B.; Durgesh, V.; Richmond, M.C. Measurements of turbulence at two tidal energy sites in puget sound, WA. IEEE J. Ocean. Eng. 2012, 34, 363-374. [CrossRef]

55. Lieberthal, B.; Huguenard, K.; Ross, L.; Liu, Z. Intratidal Variability of Water Quality in the Damariscotta River, Maine. Water 2019, 11, 2603. [CrossRef]

56. Edwards, K.A.; MacCready, P.; Moum, J.N.; Pawlak, G.; Klymak, J.M.; Perlin, A. Form drag and mixing due to tidal flow past a sharp point. J. Phys. Oceanogr. 2004, 34, 1297-1312. [CrossRef]

(C) 2020 by the authors. Licensee MDPI, Basel, Switzerland. This article is an open access article distributed under the terms and conditions of the Creative Commons Attribution (CC BY) license (http://creativecommons.org/licenses/by/4.0/). 